\title{
Prisoners of Rhodesia
}




\section{African Histories ANd Modernities}

\section{Series Editors}

Toyin Falola, University of Texas at Austin

Matthew M. Heaton, Virginia Tech

\section{Editorial Board}

Aderonke Adesanya, Art History, James Madison University

Kwabena Akurang-Parry, History, Shippensburg University

Nana Amponsah, History, University of North Carolina, Wilmington

Tyler Fleming, History, University of Louisville

Barbara Harlow, English and Comparative Literature, University of Texas at Austin

Emmanuel Mbah, History, College of Staten Island

Akin Ogundiran, Africana Studies, University of North Carolina, Charlotte

This book series serves as a scholarly forum on African contributions to and negotiations of diverse modernities over time and space, with a particular emphasis on historical developments. Specifically, it aims to refute the hegemonic conception of a singular modernity, Western in origin, spreading out to encompass the globe over the last several decades. Indeed, rather than reinforcing conceptual boundaries or parameters, the series instead looks to receive and respond to changing perspectives on an important but inherently nebulous idea, deliberately creating a space in which multiple modernities can interact, overlap, and conflict. While privileging works that emphasize historical change over time, the series will also feature scholarship that blurs the lines between the historical and the contemporary, recognizing the ways in which our changing understandings of modernity in the present have the capacity to affect the way we think about African and global histories.

\section{Published in the series}

Contemporary Africa: Challenges and Opportunities (2014)

Edited by Toyin Falola and Emmanuel M. Mbah

African Postcolonial Modernity: Informal Subjectivities and the

Democratic Consensus (2014)

By Sanya Osha

Building the Ghanaian State: Kwame Nkrumah's Symbolic Nationalism (2014)

By Harcourt Fuller

Prisoners of Rhodesia: Inmates and Detainees in the Struggle for Zimbabwean

Liberation, 1960-1980(2014)

By Munyaradzi B. Munochiveyi 


\section{Prisoners of Rhodesia}

Inmates and Detainees in the Struggle for

Zimbabwean Liberation, 1960-1980

Munyaradzi B. Munochiveyi 


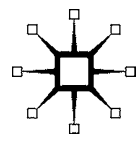

PRISONERS OF RHODESIA

Copyright (C) Munyaradzi B. Munochiveyi, 2014.

Softcover reprint of the hardcover 1st edition 2014 978-1-137-48271-6

All rights reserved.

First published in 2014 by

PALGRAVE MACMILLAN ${ }^{\circledR}$

in the United States-a division of St. Martin's Press LLC,

175 Fifth Avenue, New York, NY 10010.

Where this book is distributed in the UK, Europe and the rest of the world, this is by Palgrave Macmillan, a division of Macmillan Publishers Limited, registered in England, company number 785998, of Houndmills, Basingstoke, Hampshire RG216XS.

Palgrave Macmillan is the global academic imprint of the above companies and has companies and representatives throughout the world.

Palgrave ${ }^{\circledR}$ and Macmillan ${ }^{\circledR}$ are registered trademarks in the United States, the United Kingdom, Europe and other countries.

ISBN 978-1-349-50319-3

ISBN 978-1-137-48273-0 (eBook)

DOI $10.1057 / 9781137482730$

Library of Congress Cataloging-in-Publication Data

Munochiveyi, Munyaradzi B., author.

Prisoners of Rhodesia : inmates and detainees in the struggle for Zimbabwean liberation, 1960-1980 / by Munyaradzi B. Munochiveyi. pages $\mathrm{cm}$ - (African histories and modernities)

Includes bibliographical references and index.

1. Political prisoners-Zimbabwe-Biography. 2. National liberation movements-Zimbabwe. 3. Zimbabwe-HistoryAutonomy and independence movements. 4. ZimbabweHistory-1965-1980. 5. Zimbabwe-History-Chimurenga War, 1966-1980-Prisoners and prisons. I. Title.

DT2990.M86 2014

365.45096891-dc23

2014025380

A catalogue record of the book is available from the British Library.

Design by Newgen Knowledge Works (P) Ltd., Chennai, India.

First edition: December 2014

109876654321 
For my late Mum, Amai Sarah Munochiveyi, a strong-willed woman who refused to be bowed.

And for my dear family, my wife Rumbidzai Cindy Munochiveyi, our three sons Tino, Anesu, and Takunda, and our special daughter Sarah, all who have graciously filled a void in my life. 
This page intentionally left blank 


\section{Contents}

Acknowledgments $\quad$ ix

Glossary $\quad$ xi

1 Introduction: Suffering for the Nation: The Prison as a Site of Struggle during Zimbabwe's Liberation War I

2 The Growth of African Opposition and Intensified State Political Repression in Rhodesia, 1960-1970s

3 Getting Arrested: Oral Histories of Violence, Torture, and Arrest in Rhodesia, 1960-1979

4 Life in Detention: Oral Histories of Confinement in Rhodesian Detention Centers

5 Life Behind Bars: Oral Histories of Life inside Rhodesian Prisons, 1965-1980

6 Epilogue: Life Beyond Bars and Legacies of Incarceration in Colonial and Post-Colonial Zimbabwe, 1965-2000

Conclusion: Political Imprisonment and Memorializing Zimbabwe's Liberation Struggle

Notes

Bibliography 261

Index 269 
This page intentionally left blank 


\section{ACKNOWLEDGMENTS}

This body of work represents my standing on the shoulders of others who supported this research and the writing of this book in one way or another. More importantly, this book was made possible by the many Zimbabwean ex-political prisoners and detainees of the Rhodesian regime whom I interviewed and who shared their life stories with me. I am grateful for these people's openness to share their most painful and intimate memories with me. It was not easy for most of these people to remember their painful pasts, but they did it anyway, and invited me into their homes and gave me some of the most important lessons in history. I am particularly grateful to Mr. Victor Kuretu, chairperson of the Zimbabwe Ex-Political Prisoners, Detainees, and Restrictees Association, for putting me in touch with several of his fellow ex-prisoners and detainees. He is a truly generous man, even when we respectfully differed in our political opinions. To the courageous ex-prisoners and detainees, I say, Aluta continua, comrades!

This project developed first as a doctoral thesis at the University of Minnesota, Twin Cities, and evolved into this book through numerous interpretations and reinterpretations of data. Allen Isaacman, arguably one of the gurus of southern African history, read through the manuscript of this book multiple times and worked tirelessly to instill the discipline of rigorous intellectual work within me. His (impatient!) rejection of intellectual laziness is one of the most important lessons that has shaped my career as an historian. As a former graduate school adviser, and now as a colleague and dear friend, Allen Isaacman has always pushed me to think in different and exciting ways. Tamara Giles-Vernick also read through initial drafts of this manuscript.

My former fellow graduate students, who have all now joined the ranks of the academy, have read various versions of this manuscript countless times, and their dedication to perfection meant that they helped me to avoid making embarrassing mistakes. Julie Marie "Zag" Weiskopf read many chapter scripts closely, and picked out all the embarrassing spelling mistakes and awkward grammar. As my former cohort-mate, Julie was always generous with her time from my first days in the United States to my last days at the University of Minnesota. No one has cheered me on like Julie. The two of us, of 
course, made quite a dynamic duo! We wrote our doctoral preliminary exams together, sharing ideas and pushing each other to the limits of academic excellence. She is a great friend who genuinely cares for others. Her parents in Spokane, Washington, Robert and Roberta Weiskopf, love my family dearly. I am also grateful to my good buddies and former fellow graduate students Jones "Nuswe" Sichali, Terry "TMM" Mashingaidze, Clement "Rekime" Masakure, and Oswald "Men-at-Work" Masebo. These friends kept me sane throughout my graduate career, and have continued to be generous with witty comments and critiques whenever I bounced off my ideas on them.

I also acknowledge my former mentors at my undergraduate alma mater, the University of Zimbabwe. The economic history department faculty first put me on this great journey in 1999 when I arrived at UZ as a freshman. Prof. Alois Mlambo immediately noticed something of a historian in me, and encouraged me to develop my skills as an historian. He oversaw my first major piece of historical writing, that is, my Honors dissertation, and made sure that it was a first-class and distinctive piece of work. Prof. Mlambo is one of the hardest working and humblest of mentors I have interacted with so far. Many friends and colleagues who passed through his hands testify to his caring, respectful, and sensitive nature as a mentor. I am also deeply indebted to my other history teachers at UZ, namely Dr. Pius Shungudzapera Nyambara, a genuine mentor and friend, Dr. J. P. Mtisi, a patient father-figure, and Dr. V. E. M. Machingaidze, a no-nonsense but astute and respectful teacher. All these academics helped to introduce me, in various ways, to the whys and wherefores of history. The economic history department at UZ also served as my institution of affiliation during my research for this book between 2006 and 2007.

My family, Rumbie, Tino, Anesu, Takunda, and Sarah are my most prized possession. Everything else does not matter except these five people who have generously filled a void in my life. Rumbie has been a very supportive and caring wife, which is not easy with a husband usually buried in documents, transcriptions, and countless drafts of scholarly work for long periods of time (not to mention the lonely nights and months when I am away doing research in Zimbabwe).

Lastly, all the shortcomings in this book are entirely my responsibility.

This research was funded by The Graduate School, University of Minnesota (Doctoral Dissertation Fellowship: 2007-2008); The MacArthur Program (MacArthur and Compton Fellowships: 2003-2008), University of Minnesota History Department (GRPP Fellowship: 2006-2007); and the College of the Holy Cross (Junior Faculty Research and Publication Fund: 2009-2010). 


\section{GLoss ARY}

Rhodesia "Rhodesia” was Zimbabwe's colonial name from 1890 to 1979 , in recognition of Cecil Rhodes, who engineered British settlers' occupation of the country. After the end of settler colonial rule in 1980 , the country's name became Zimbabwe, in recognition of one of the country's pre-colonial empires, Dzimbahwe.

Township(s) Urban spaces where the majority of Africans stayed Salisbury Rhodesia's capital city (now Harare)

Bulawayo The second largest city in Rhodesia (and Zimbabwe)

Umtali The third largest city in Rhodesia (now Mutare)

MAJOR POLITICAL PARTIES:

Youth League An African political organization in the late 1950s

SR-ANC Southern Rhodesia African National Congress (African political party), formed 1959

NDP National Democratic Party (African political party), formed 1960

ZAPU Zimbabwe African People's Union (African political party), formed 1963

ZANU Zimbabwe People's African National Union (African political party), formed 1964

ZANLA Zimbabwe African National Liberation Army (armed guerrilla wing of ZANU), 1970s

ZIPRA Zimbabwe People's Revolutionary Army (armed guerrilla wing of ZAPU), 1970s

RF Rhodesia Front (An exclusively white supremacist Rhodesian political party led by Ian Douglas Smith that invoked and led the U.D.I.), 1962 and 1979 LOMA Law and Order Maintenance Act (1960, amended 1963) 
UDI

Major Prisons

Major Detention Centers
Acronym for the white minority Rhodesian government after its premier, Ian Douglas Smith, declared what he called "Unilateral Declaration of Independence" on the November 11, 1965, which meant declaring independence from imperial Britain.

Rhodesian Security Forces Collective name for Rhodesian police, paramilitary crack units, and soldiers fighting against African nationalists and guerrillas. These forces included the Rhodesia British South Africa Police (BSAP), police crack units such as the Special Branch, the Criminal Intelligence Department (CID), and counterinsurgency military units such as the Selous Scouts.

Salisbury Prison, Gwelo Prison, Chikurubi Maximum Prison, Khami Maximum Prison, Goromonzi Prison Gonakudzingwa, Sikombela, Wha Wha 